BY DENISE GILBERT, PH.D

\title{
DISAPPOINTING FIRST QUARTER
}

n stark contrast to the euphoric rally of 1991 , the stock-price performance of the biotech group in 1992 has been dismal. Smith Barney's biotechnology industry price index-containing 57 drug-related biotechnology companies-rose 144 percent in 1991. Yet, as of mid-April, it has slipped 55 percent from its high in midJanuary. Uncertainty in the overall market, weakness in the price performance of established drug stocks, and a series of biotech-related disappointments at the U.S. Food and Drug Administration (FDA, Bethesda, MD) all factored into the price weakness. Sentiment switched from the almost blind enthusiasm over the potential of biotech drugs that characterized 1991 to widespread skepticism and the "show-me" attitude of 1992.

Based on 10-year historical price trends of the group, we believe that a critical turning point is upon us. Prices could either rebound, continuing the third "up" cycle in the 10-year history of the industry, or prices could continue to weaken, starting the third "down" cycle. We had expected a 1992 "wave" of biotech drug approvals to initiate a rebound. However, now that approval of Centocor's (Malvern, PA) Centoxin is delayed, we are concerned that the remaining drugs are not large enough to fuel a price rally. At this time, we know of no events over the next few months that will turn this group around. Of the seven drugs expected to be approved in 1992, Centocor's Centoxin was to be the largest and first approved. The other six biotech products include Centocor's Myoscint, Chiron's (Emeryville, CA) IL-2, Cytogen's (Princeton, NJ) OncoScint, Genentech's (S. San Francisco, CA) Factor VIII, Genetics Institute's (Cambridge, MA) Factor VIII, and Xoma's (Berkeley, CA) CD5 Plus.

\section{Dismal price performance}

Every stock in our biotech index is down as of mid-April, with one exception, Immunomedics (Warren, NJ) +14 percent. The worst performers include U.S. Bioscience (W. Conshohocken, PA) -71 percent, Centocor -70 percent, Immunex (Seattle, WA) -57 percent, MGI Pharma (Minneapolis, MN) -57 percent, Somatogen (Boulder, CO) -51 percent, DNX (Princeton, NJ) 48 percent, Immune Response (San Diego, CA) -48 percent, and Synergen (Boulder, CO) -48 percent. Even the best performers have experienced substantial price weakness: Cytogen -14 percent, Genta (San Diego, CA) -13 percent, Repligen (Cambridge, MA) -13 percent, and Genelabs (Redwood City, CA) -19 percent.

Approximately 75 percent of the 35 companies included in the index that have gone public in the last 15 months are at or below their initial public offering (IPO) price. These stocks are now at prices that, on average, represent a 2 percent discount to the IPO price, compared to an average premium of 100 percent at their highs.

\section{First tier suffers}

Our universe of companies is divided into three tiers. Six of the seven first-tier companies are profitable. The $15 \mathrm{sec}$ ond-tier companies are projected to be profitable in the mid-1990s. The 35 third-tier companies are not expected to earn significant profits until the late 1990s. As of mid-A pril, first-tier companies have suffered the most. As a group, they have dropped 47 percent, while second-tier companies have fallen 33 percent and third-tier firms have dropped 34 percent.

\section{String of disappointments}

A series of product-related letdowns shattered investors' confidence in their ability to choose successful biotech companies. U.S. Bioscience plunged 44 percent (from $\$ 32$ to $\$ 18$ ) in late January when an FDA advisory committee failed to recommend approval of its cancerrelated drug, Ethyol. MGI Pharma dropped 50 percent (from $\$ 22$ to $\$ 11$ ) in February when it announced that phase-III trials for MGI 136, a drug that detoxifies chemotherapeutic agents, were halted because of safety concerns. Immunex dropped 25 percent (from \$42 to \$32) in April, when it announced that in this year's first quarter, and perhaps second quarter, it would show losses due to significantly lower sales of GM-CSF.

The most significant disappointment has been continued delays in FDA approval of Centocor's Centoxin. Centocor's stock dropped 20 percent (from \$41 to \$33) in February when it announced that FDA had raised additional questions. Its stock fell another 41 percent (from $\$ 31$ to $\$ 19$ ) in April when it announced that FDA might require a second clinical trial prior to Centoxin approval.

\section{Closing equity window?}

Equity financings for drug-related biotech companies continued at a feverish pitch for the first two months of 1992, only to slow in March. In this year's first quarter, 22 transactions were completed that raised $\$ 1$ billion, including 10 IPOs that raised $\$ 478$ million. This compares to 65 transactions raising $\$ 3.2$ billion for all of 1991 , including 28 IPOs that raised $\$ 980$ million. Nine offerings still are pending, including seven IPOs.

It will be extremely difficult to convince investors to invest in a new IPO rather than an existing public company, however. This is because over 30 percent of the 57 companies in our universe are now at market values of less than or equal to $\$ 100$ million; 15 percent are trading at $1.0 \mathrm{x}-1.5 \mathrm{x} /$ cash or book value; and 50 percent are trading at a multiple of cash or book value of $2 \mathrm{x}$ or less.

\section{Price volatility}

Over the last year, we have been disturbed by the increase in the price volatility of biotech stocks. Our index soared 80 points between mid-November 1991 and mid-January 1992 and then dropped more than 135 points between mid-January 1992 and mid-April 1992. Intra-day price swings in individual stocks of 5 percent to 10 percent, without a change in company-specific fundamentals, have been common. The sentiment can best be characterized as a "love-hate" relationship.

Perhaps this fluctuation has been exacerbated by the entry of investors who do not really understand the risks inherent in biotechnology, as well as by company managements that may be getting too "good" at presenting the "best side" of their story at roadshows. The biotech group is now dominated by new public companies, companies that need to learn to manage expectations. We hope that over time, the lovehate relationship with biotech will be modified to one of measured optimism. We continue to believe that biotechnology will have a revolutionary impact on medicine.

Denise Gilbert, Ph.D., is a biotechnology analyst at Smith Barney (San Francisco). A version of this story appeared in Smith Barney's April 30 Biotechnology Industry Quarterly Report. 